\title{
Vitamin D level in children with juvenile idiopathic arthritis and its correlation with clinical picture of the disease
}

\author{
Stężenie witaminy D u dzieci chorych na młodzieńcze idiopatyczne zapalenie \\ stawów a obraz kliniczny choroby
}

\author{
Joanna Szymańska-Kałuża, Małgorzata Biernacka-Zielińska, Jerzy Stańczyk, \\ Elżbieta Smolewska \\ Department of Pediatric Cardiology and Rheumatology, Medical University of Lodz \\ Klinika Kardiologii i Reumatologii Dziecięcej Uniwersytetu Medycznego w Łodzi
}

Key words: juvenile idiopathic arthritis, vitamin D, clinical picture of the disease.

Słowa kluczowe: młodzieńcze idiopatyczne zapalenie stawów, witamina D, obraz kliniczny choroby.

\begin{abstract}
Summary
Objectives: To evaluate the concentration of $1,25(\mathrm{OH}) 2 \mathrm{D}$ and $25(\mathrm{OH}) \mathrm{D}$ in patients with newly diagnosed juvenile idiopathic arthritis (IIA) determined before starting therapy and attempt to demonstrate the relationship between serum vitamin D metabolites and the activity and subtype of the disease.

Material and methods: A total of 50 children aged 2-16 years, who were diagnosed with JIA, were enrolled in the study. The control group comprised 28 children with matching age and gender, hospitalized due to circulatory system functional disorder. The level of the active metabolite of vitamin $\mathrm{D}$ in the sera was determined using the radioimmunoassay method and the $25(\mathrm{OH}) \mathrm{D}$ was tested using an ELISA immunoassay.

Results: The concentration of 1,25(OH)2D in the serum of children with the disease was statistically significantly lower compared to the children in the control group $(34.86 \pm 17.14 \mathrm{pg} / \mathrm{ml}$ vs. $48.47 \pm 17.99 \mathrm{pg} / \mathrm{ml}$, $p=0.0015$ on average, respectively). However, the concentrations of $25(\mathrm{OH}) \mathrm{D}$ in both groups were comparable $(17.36 \pm 8.44 \mathrm{ng} / \mathrm{ml}$ vs. 17.36 $\pm 16.29 \mathrm{ng} / \mathrm{ml}$ on average), but lower than the recommended rate (i.e. $<30 \mathrm{ng} / \mathrm{ml}$ ). Higher mean concentrations of the active form of vitamin $D$ in the serum of children with low activity of the disease compared to medium and high activity, but without statistical significance, was found. However, mean concentrations of $25(\mathrm{OH}) \mathrm{D}$ were the highest in the group with high disease activity but without statistical significance. Higher mean concentrations of the active form of vitamin $D$ and $25(\mathrm{OH}) \mathrm{D}$ in the serum of children with oligoarthritis disease were demonstrated but without statistical significance.

Conclusions: Our results confirm the data on commonly occurring vitamin D deficiency in the developmental age population, which indi-
\end{abstract}

\section{Streszczenie}

Cel pracy: Ocena stężeń: 1,25(OH)2D i 25(OH)D u dzieci z nowo ustalonym rozpoznaniem MIZS, przed rozpoczęciem terapii oraz próba wykazania ewentualnych zależności pomiędzy stężeniami metabolitów witaminy $D$ a aktywnością i postacią choroby.

Materiał i metody: Badaniem objęto 50 dzieci (40 dziewcząt i 10 chłopców) w wieku 2-16 lat, u których ustalono rozpoznanie MIZS na podstawie kryteriów z Edmonton (2001 r.). U wszystkich pacjentów oceniono postać oraz aktywność choroby. Grupę kontrolną stanowito 28 dzieci zdrowych, odpowiednio dobranych pod względem płci i wieku, hospitalizowanych z powodu czynnościowych zaburzeń układu krążenia. Stężenie aktywnego metabolitu witaminy D [1,25(OH)2D] w surowicy oznaczono z wykorzystaniem metody radioimmunologicznej, a 25(OH)D zbadano za pomocą metody immunoenzymatycznej - ELISA.

Wyniki: Stężenie 1,25(OH)2D w surowicy dzieci chorych było istotnie statystycznie mniejsze w porównaniu ze stężeniem u dzieci z grupy kontrolnej (średnio odpowiednio: $34,86 \pm 17,14 \mathrm{pg} / \mathrm{ml}$ vs 48,47 $\pm 17,99$ $\mathrm{pg} / \mathrm{ml}, p=0,0015)$. Stężenia 25(OH)D w obu grupach były natomiast porównywalne (śr. 17,36 $\pm 8,44 \mathrm{ng} / \mathrm{ml}$ vs 17,36 $\pm 16,29 \mathrm{ng} / \mathrm{ml}$ ), ale niższe od zalecanego poziomu (tj. < $30 \mathrm{ng} / \mathrm{ml}$ ). Stwierdzono większe średnie stężenia aktywnej formy witaminy $D[1,25(\mathrm{OH}) 2 \mathrm{D}]$ w surowicy dzieci chorych z niską aktywnością choroby w porównaniu ze średnią i wysoką aktywnością, ale bez istotności statystycznej. Podobnie, średnie stężenia 25(OH)D chociaż były najwyższe w grupie dzieci z wysoką aktywnością choroby, nie były znamienne statystycznie. Wykazano większe średnie stężenia aktywnej formy witaminy $D$ i 25(OH)D w surowicy dzieci ze skąpostawową postacią choroby, jednak bez znamienności statystycznej.

\section{Address for correspondence}

lek. Joanna Szymańska-Kałuża, Department of Pediatric Cardiology and Rheumatology, Medical University of Lodz, Sporna 36/50, 91-73 Łódź, e-mail: jszymanskakaluza81@gmail.com

Submitted: 25.06 .2013 
cates the need for proper supplementation. Our finding - insufficiency of $25(\mathrm{OH}) \mathrm{D}$ as well as lower level of $1,25(\mathrm{OH}) 2 \mathrm{D}$ compared to healthy children - can be the prerequisite for routine evaluation of metabolites of vitamin D in patients with JIA. There were no correlations between activity, type of JIA and metabolites of vitamin D.

\section{Introduction}

Juvenile idiopathic arthritis (IIA) is the most frequent chronic systemic connective tissue disease occurring at developmental age. It is characterized by chronic arthritis, lasting for at least six weeks, in children below 16 years of age. The aetiopathogenesis of the disease is complex and still not fully elucidated. Recently, more and more pathogenetic significance has been ascribed to vitamin D, which, through VDRs (intracellular vitamin $D$ receptors) present on most immune system cells (i.e. macrophages, dendritic cells, activated T-cells), possibly plays the role of an immune response modulator [1]. The studies carried out to date demonstrated that vitamin $D$ deficiency was associated with the development of autoimmune diseases such as type 1 diabetes mellitus, multiple sclerosis or inflammatory bowel diseases. A significant deficiency of that vitamin was also found in patients with rheumatoid arthritis (RA), systemic lupus erythematosus, Behçet disease, scleroderma or polymyositis/dermatomyositis. Additional evidence supporting the thesis that vitamin D plays an important role was provided by the fact that supplementation with active form of that medication, $1,25(\mathrm{OH})_{2} \mathrm{D}$ completely inhibited the development of autoimmune diseases in studies in experimental models [2-4]. It was also demonstrated that vitamin D influenced directly and indirectly the proliferation and function of T-cells

Table I. Characteristics of the studied children with juvenile idiopathic arthritis (JIA)

\begin{tabular}{|llll|}
\hline \multicolumn{4}{|c|}{ General characteristics of children with JIA } \\
\hline Total number of studied subjects $(n=59)$ & $N$ & $\%$ \\
\hline Gender & girls & 40 & 80 \\
\cline { 2 - 4 } & boys & 10 & 20 \\
\hline $\begin{array}{l}\text { Type of onset } \\
\text { of JIA form }\end{array}$ & oligoarticular & 31 & 62 \\
\cline { 2 - 4 } & polyarticular & 16 & 32 \\
\cline { 2 - 4 } & systemic & 3 & 6 \\
\hline \multirow{2}{*}{$\begin{array}{l}\text { Activity of } \\
\text { the disease }\end{array}$} & low & 28 & 56 \\
\cline { 2 - 4 } & medium & 9 & 18 \\
\cline { 2 - 4 } & high & 13 & 26 \\
\hline
\end{tabular}

Wnioski: Uzyskane wyniki potwierdzają dane o powszechnie występującym niedoborze witaminy D w populacji wieku rozwojowego, co wskazuje na konieczność odpowiedniej suplementacji. Zarówno niedobór 25(OH)D, jak i zmniejszone w stosunku do zdrowych rówieśników stężenie aktywnej formy -1,25(OH)2D, może być przesłaniem do rutynowego oznaczania metabolitów witaminy D u pacjentów z MIZS. Przeprowadzone badania nie wykazały znamiennej zależności pomiędzy metabolitami witaminy D a postacią i aktywnością MIZS.

that play the key role in the pathogenesis of RA and JIA. Stimulation of $\mathrm{T} C \mathrm{CD} 4+/ \mathrm{CD} 25$-cells in the presence of $1,25(\mathrm{OH})_{2} \mathrm{D}$ inhibited the production of proinflammatory cytokines including IFN- $\gamma$ (interferon $\gamma$ ), IL-17 (interleukin 17) and IL-21, and induced high expression of the proteins CTLA-4 and FoxP3, characteristic of regulatory cells [5].

There are relatively few studies assessing the effect of vitamin D level on the course and activity of the inflammatory process in children with JIA. For that reason, the aim of the study was to assess the concentration of that vitamin's metabolites in the sera of patients with JIA compared with the concentration in the control group of children, and to analyse the correlation of the studied parameters with the clinical picture of the disease.

\section{Material and methods}

The study involved 50 children (40 girls and 10 boys) aged $2-16$ years (mean age $9.4 \pm 5.52$ years) hospitalised in the Department of Pediatric Cardiology and Rheumatology, Medical University of Lodz in the years 2010-2012, with newly diagnosed JIA, in whom no treatment was instituted yet. The diagnosis of the disease was made based on the Edmonton criteria (2001) [6]. The activity of the pathological process was determined using JADAS-27 (Juvenile Arthritis Disease Activity Score) [7]. That score consists of global disease activity assessment by a doctor, global assessment of the child's well-being by the patient/parent, number of joints involved, and ESR value. On its basis three grades of disease activity are distinguished: low, medium and high. The general characteristics of JIA patients are presented in Table I.

The control group included 28 healthy children aged 2-16 years (mean age $9.67 \pm 3.04$ years) hospitalised due to circulatory system function disorders (fainting) after ruling out any organic disease. No renal function disturbances were found in either group of children.

All patients and their parents/guardians were informed about the aim of the study and gave consent to its conduction. The project of the study received a positive opinion of the Bioethical Committee at the Medical University of Łódź.

In all children the following concentrations were determined: active vitamin $D$ form in the serum by radioimmunoassay method using RIA-CT test, Bio Source Europe 
S.A., and 25(OH)D using ELISA test, EUROIMMUN. Blood for the above-mentioned tests was taken once by an antecubital venipuncture during routine diagnostic tests in the morning in autumn-winter-spring seasons. The sera obtained after centrifugation were kept frozen at $-70^{\circ} \mathrm{C}$ in plastic tubes. No child was taking any vitamin D preparations. The obtained results were statistically analysed using the STATISTICA 10.0 software. The differences between the values obtained in the control and study groups were checked in respect of statistical significance; two-sample parametric Student's $t$-test for means and non-parametric Mann-Whitney U-test were used. Verification of normal distribution was performed using the Kolmogorov-Smirnov test. Two-sided tests were used for the analysis, and $p<0.05$ was accepted as the statistical significance threshold. The analysis of the correlation between the studied parameters in the study group was performed by calculating Pearson's linear correlation coefficient or Spearman's rank correlation coefficient.

\section{Results}

A statistically significantly lower serum concentration of the active vitamin $\mathrm{D}$ form, $1,25(\mathrm{OH})_{2} \mathrm{D}$, was found in the diseased children, compared with the concentration in the control group (mean: $34.86 \pm 17.14 \mathrm{pg} / \mathrm{ml}$ vs. $48.47 \pm 17.99$ $\mathrm{pg} / \mathrm{ml}$, respectively, $p<0.01$ ) (Fig. 1). The concentrations of $25(\mathrm{OH}) \mathrm{D}$ in both groups were, however, similar (mean: $17.36 \pm 8.44 \mathrm{ng} / \mathrm{ml}$ vs. $17.36 \pm 16.29 \mathrm{ng} / \mathrm{ml})$, but lower than the recommended level (i.e. $<30 \mathrm{ng} / \mathrm{ml}$ ) (Fig. 2).

\section{Analysis of the concentrations of vitamin D metabolites depending on the activity of the disease}

No statistical significance was found between the mean concentration of the active vitamin form, $1,25(\mathrm{OH})_{2} \mathrm{D}$, and JIA activity, although the concentration was higher in children with low disease activity compared with that in children with medium and high disease activity (mean: 38.96 $\pm 18.52 \mathrm{pg} / \mathrm{ml}$ vs. $31.44 \pm 16.61 \mathrm{pg} / \mathrm{ml}$ and $28.38 \pm 12.44 \mathrm{pg} / \mathrm{ml}$, respectively) (Fig. 3). Similarly, no significant correlation was found between the mean $25(\mathrm{OH}) \mathrm{D}$ concentration and the inflammatory condition intensity (mean: $18.25 \pm 7.05$ $\mathrm{pg} / \mathrm{ml} v \mathrm{vs} 16.92 \pm 9.87 \mathrm{pg} / \mathrm{ml}$ and $17.43 \pm 5.61$, respectively, $p>0.05)$.

\section{Analysis of the concentrations of vitamin D metabolites depending on type of onset of juvenile idiopathic arthitis}

In spite of the fact that in children with oligoarticular type of onset a slightly higher mean concentration was found of the active vitamin D form, $1,25(\mathrm{OH})_{2} \mathrm{D}$, compared with the concentration in children with polyarticular and systemic (mean: $38.03 \pm 17.77 \mathrm{pg} / \mathrm{ml}$ vs. $31.84 \pm 12.75$ $\mathrm{pg} / \mathrm{ml}$, respectively), it was, however, without any statistical significance (Fig. 4). Despite the fact that the mean $25(\mathrm{OH}) \mathrm{D}$ concentrations were highest in the group of chil-

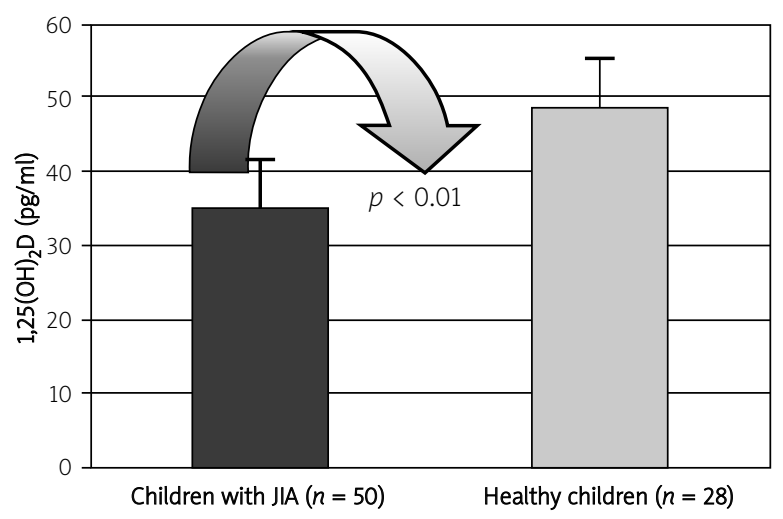

Fig. 1. Levels of $1,25(\mathrm{OH})_{2} \mathrm{D}$ in the serum of children with JIA and in the control group.

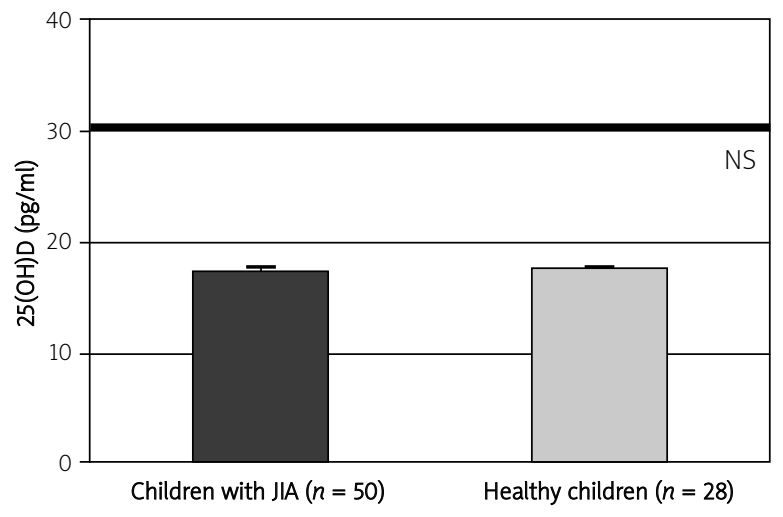

Fig. 2. Levels of $25(\mathrm{OH}) \mathrm{D}$ in the serum of children with JIA and in the control group.

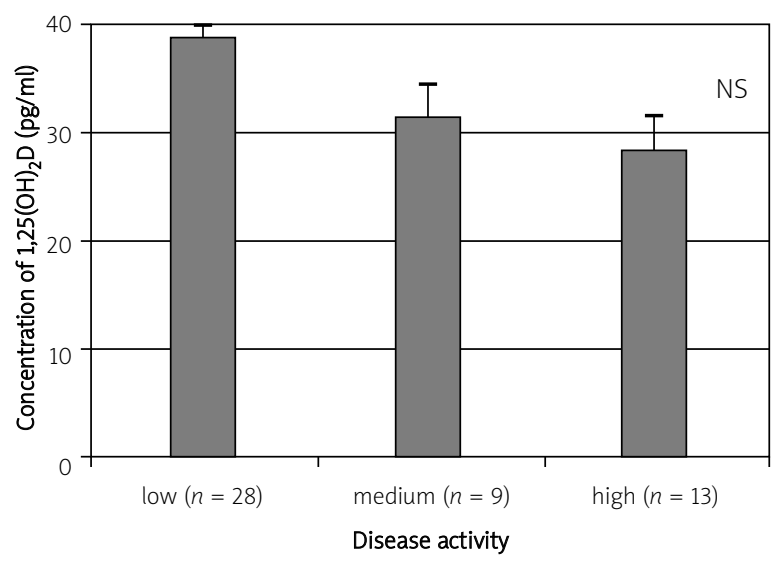

Fig. 3. Analysis of the concentrations of $1,25(\mathrm{OH})_{2} \mathrm{D}$ depending on the activity of disease. 


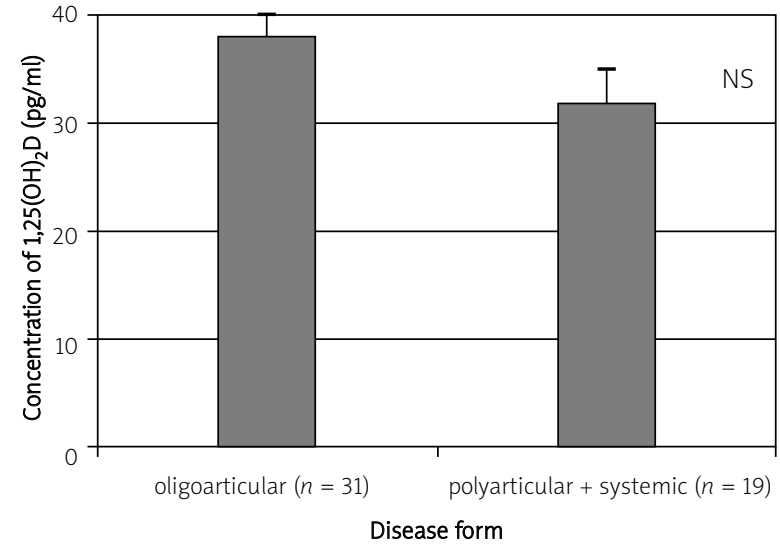

Fig. 4. Analysis of the concentrations of $1,25(\mathrm{OH})_{2} \mathrm{D}$, depending on the type of onset of the disease.

dren with oligoarticular type of onset compared with those in children with polyarticular and systemic (mean: 18.24 $\pm 9.73 \mathrm{pg} / \mathrm{ml}$ vs. $15.84 \pm 4.91 \mathrm{pg} / \mathrm{ml}$, respectively), no statistical significance was demonstrated (Fig. 5).

\section{Discussion}

The reports from recent years have shown that vitamin $\mathrm{D}$, apart from its classic function consisting in regulating the calcium-phosphate homeostasis, also plays a role in regulating the immune system. The results of numerous studies proved that a deficiency of that vitamin is associated with an increased risk of development of autoimmune diseases, cardiovascular diseases or some malignancies [8-14].

In the study described, an evaluation was conducted of the serum concentrations of vitamin $D$ metabolites, $1,25(\mathrm{OH})_{2} \mathrm{D}$ and $25(\mathrm{OH}) \mathrm{D}$, in children with JIA before starting the treatment and in children from the control group. Besides that, the correlation was assessed of these parameters with the activity and course of JIA. The analysis of the obtained results demonstrated that although the concentration of the active vitamin D form, both in the group of children with JIA and in the control group, was within the normal range $(\mathrm{N}: 2-60 \mathrm{pg} / \mathrm{ml})$, the mean values of $1,25(\mathrm{OH})_{2} \mathrm{D}$ concentration were significantly lower in the patients compared with those in the control group. The parameter best reflecting the reserves of vitamin $D$ in the body was 25-hydroxycholecalciferol [25(OH)D]. The mean values of its concentration in both groups were similar but below the recommended level, i.e. < $30 \mathrm{ng} / \mathrm{ml}[15,16]$.

In the recently published study of 2012, Baykal et al. demonstrated that the mean 25(OH)D concentrations were statistically significantly lower in RA patients compared with those in the control group. In over $90 \%$ of the studied sub-

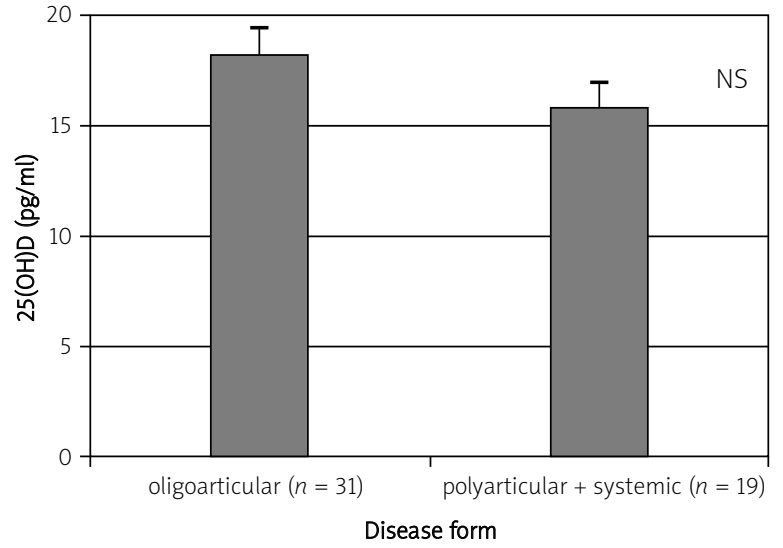

Fig. 5. Analysis of the concentrations of $25(\mathrm{OH}) \mathrm{D}$, depending on the type of onset of the disease.

jects the authors found serum $25(\mathrm{OH}) \mathrm{D}$ concentrations decreased below $30 \mathrm{ng} / \mathrm{ml}$ [17].

The issue of widespread vitamin D deficiency has already been extensively studied both in the population at developmental age and in adult patients with connective tissue diseases, but studies on that topic in children with JA are scarce.

In the studies conducted as yet, the authors searched for a possible correlation between 25(OH)D deficiency and the course of the pathological process, and varying results were obtained. Only a few publications confirmed the correlation between rheumatoid process activity and vitamin D concentration in children with JIA. Reed et al. demonstrated in their paper that in children with JIA and systemic lupus erythematosus the concentrations of both $25(\mathrm{OH}) \mathrm{D}$ and $1,25(\mathrm{OH})_{2}$ D were decreased and additionally correlated with disease activity, but the study group of patients was heterogeneous in respect of the underlying disease, disease duration and therapy conducted [18]. Pelajo et al., similarly as in our study, demonstrated that children with newly diagnosed JIA had 25(OH)D deficiencies, and observed no correlation between decreased $25(\mathrm{OH}) \mathrm{D}$ concentration and pathological process activity in patients with untreated JIA [19]. An innovation in our study, contrary to the study by Pelajo et al., was the assessment not only of 25(OH)D but also of its active metabolite in the group of children with JIA, in whom no treatment was instituted yet (including vitamin D supplementation, which is used in cases of potential steroid therapy), compared with the control group.

Rossini et al. observed a correlation between low 25(OH)D concentration and high activity of the disease in patients with RA and poor response to the administered treatment [20]. Turhanoğlu et al. also confirmed the occurrence of the lowest vitamin $D$ values in patients with high activity of the rheumatoid process (measured using 
DAS28, HAQ, CRP, ESR) [21]. Similarly, Cutolo et al. demonstrated a significantly negative correlation of $25(\mathrm{OH}) \mathrm{D}$ concentration with disease activity assessed using the DAS28 index in adult patients with RA, who lived in northern as well as southern Europe, which suggested that not only age, race, diet and degree of exposure to sunlight exert an influence on serum 25(OH)D concentration. They found in addition that patients with a high disease activity are at the highest risk of vitamin D deficiency, which possibly could be explained by limited physical activity, accompanying pain complaints and insufficient exposure to sunlight [22].

In other reports decreased serum 25(OH)D concentrations were observed in patients with RA and no statistically significant correlation with disease activity was confirmed. Baykal et al. failed to demonstrate the mentioned correlation, assessing the activity of the disease by means of DAS28 index, CRP concentration and ESR value [17]. Similar results were obtained by Baker et al., who assessed the initial vitamin $\mathrm{D}$ level in adult patients in a randomized clinical trial with golimumab. They found a $25(\mathrm{OH}) \mathrm{D}$ deficiency in over $48 \%$ of the studied subjects, although without any significant correlation between the decreased vitamin D level and the activity and course of the disease [23].

The results obtained by us failed to demonstrate any significant correlation between disease activity determined according to JADAS-27 criteria and serum vitamin D concentrations in children with JIA, although higher 1,25(OH)2D levels were accompanied by low activity of the rheumatoid process. Besides that, we could not find any significant correlation between vitamin D level and type of onset of the disease, although in the group of children with the oligoarticular type of onset the mean concentrations of both the active form of vitamin D and 25(OH)D were higher compared with those in the children with the polyarticular and systemic type of onset.

\section{Conclusions}

The above-mentioned results confirm the data about the widespread vitamin $D$ deficiency in the population at developmental age, which suggests a necessity of adequate supplementation. Both 25(OH)D deficiency and a decreased, in comparison with healthy peers, level of the active form $-1,25(\mathrm{OH})_{2} \mathrm{D}-$ can be the grounds for routine determination of vitamin D metabolites in patients with JIA. In the studies carried out, no significant correlation was demonstrated between vitamin $D$ metabolites and the type of onset and activity of JIA. The biological function of vitamin D in regulation of the immune response points to its extremely important role in the pathogenesis of diseases of autoimmune origin (including the juvenile form of rheumatoid arthritis). Further studies on the effect of vitamin D on the immune system are indispensable in order to use it as a both a preventive and a therapeutic strategy in those diseases.

Authors declare no conflict of interests.

The work was supported by the funds from the Medical University of Lodz, No. 502-03/8-000-01/502-64-055.

\section{References}

1. Baeke F, Takiishi T, Korf H, et al. Vitamin D: modulator of the immune system. Curr Opin Pharmacol 2010; 10: 482-496.

2. Cantorna MT, Yu S, Bruce D. The paradoxical effects of vitamin D on Type 1 mediated immunity. Mol Aspects Med 2008; 29: 369-375.

3. Cutillas-Marco E, Morales-Suárez-Varela MM, et al. Serum 25hydroxyvitamin $D$ levels in patients with cutaneous lupus erythematosus in a Mediterranean region. Lupus 2010; 19: 810-814.

4. Pelajo CF, Lopez-Benitez JM, Miller LC. Vitamin D and autoimmune rheumatologic disorders. Autoimmun Rev 2010; 9: 507-510.

5. Jeffery LE, Burke F, Mura M, et al. 1,25-Dihydroxyvitamin D3 and IL-2 combine to inhibit $T$ cell production of inflammatory cytokines and promote development of regulatory $\mathrm{T}$ cells expressing CTLA-4 and FoxP3. J Immunol 2009; 183: 5458-5467.

6. Petty RE, Southwood TR, Manners P, et al. International League of Associations for Rheumatology. International League of Associations for Rheumatology classification of juvenile idiopathic arthritis: second revision, Edmonton, 2001. J Rheumatol 2004; 31: 390-392.

7. Consolaro A, Ruperto N, Bazso A, et al. Paediatric Rheumatology International Trials Organisation. Development and validation of a composite disease activity score for juvenile idiopathic arthritis. Arthritis Rheum 2009; 61: 658-666.

8. Cutolo M, Plebani M, Shoenfeld Y, et al. Vitamin D endocrine system and the immune response in rheumatic diseases. Vitam Horm 2011; 86: 327-351.

9. Littorin B, Blom P, Schölin A, et al. Lower levels of plasma 25hydroxyvitamin $D$ among young adults at diagnosis of autoimmune type 1 diabetes compared with control subjects: results from the nationwide Diabetes Incidence Study in Sweden (DISS). Diabetologia 2006; 49: 2847-2852.

10. Szodoray P, Nakken B, Gaal J, et al. The complex role of vitamin D in autoimmune diseases. Scand J Immunol 2008; 68: 261-269.

11. Ascherio A, Munger KL, Simon KC. Vitamin D and multiple sclerosis. Lancet Neurol 2010; 9: 599-612.

12. Joseph AJ, George B, Pulimood AB, et al. $25(\mathrm{OH})$ vitamin D level in Crohn's disease: association with sun exposure and disease activity. Indian J Med Res 2009; 130: 133-137.

13. WangTJ, Pencina MJ, Booth SL, et al. Vitamin D deficiency and risk of cardiovascular disease. Circulation 2008; 117: 503-511.

14. Forman JP, Curhan GC, Taylor EN. Plasma 25-hydroxyvitamin D levels and risk of incident hypertension among young women. Hypertension 2008; 52: 828-832.

15. Lips P. Relative value of 25(OH)D and 1,25(OH)2D measurements. J Bone Miner Res 2007; 22: 1668-1671.

16. Dobrzańska A i Zespół Ekspertów. Polskie zalecenia dotyczące profilaktyki niedoboru witaminy D. Med Prakt Pediatr 2010; 1: 40-45. 
17. Baykal T, Senel K, Alp F, et al. Is there an association between serum 25-hydroxyvitamin D concentrations and disease activity in rheumatoid arthritis? Bratisl Lek Listy 2012; 113: 610-611.

18. Reed A, Haugen M, Pachman LM, et al. Abnormalities in serum osteocalcin values in children with chronic rheumatic diseases. J Pediatr 1990; 116: 574-580.

19. Pelajo CF, Lopez-Benitez JM, Kent DM, et al. 25-hydroxyvitamin $D$ levels and juvenile idiopathic arthritis: Is there an association with disease activity? Rheumatol Int 2012; 32: 3923-3929.

20. Rossini M, Maddali Bongi S, La Montagna G, et al. Vitamin D deficiency in rheumatoid arthritis: prevalence, determinants and associations with disease acitivty and disability. Arthritis Res Ther 2010; 12: R216.

21. Turhanoğlu AD, Güler H, Yönden Z, et al. The relationship between vitamin $D$ and disease activity and functional health status in rheumatoid arthritis. Rheumatol Int 2011; 31: 911-914.

22. Cutolo M, Otsa K, Laas K, et al. Circannual vitamin D serum levels and disease activity in rheumatoid arthritis: Northern versus Southern Europe. Clin Exp Rheumatol 2006; 24: 702-704.

23. Baker JF, Baker DG, Toedter G, et al. Associations between vitamin $D$, disease activity, and clinical response to therapy in rheumatoid arthritis. Clin Exp Rheumatol 2012; 30: 658-664. 